\title{
CONSTRUCTION AND COMMUNICATION \\ OF FALCHERA: AN INA-CASA NEIGHBOURHOOD IN TURIN BY GIOVANNI ASTENGO
}

\section{A B S T R A C T}

Falchera is a social housing estate in the periphery of Turin designed by Giovanni Astengo and a group of architects in the fifties, in the context of the INA-Casa program. Imagined as an ideal organic neighbourhood, it was representative of an aspiration to a community life in peri-urban areas developed within the Comunità movement lead by Adriano Olivetti. Architecture was one of the media used to communicate an ideal of life. The design process followed by Astengo and the architects of Falchera thus had to adapt to communication strategies. The concept of organic neighbourhood was developed down to the scale of architectural detail through the use of an hexagonal pattern which created many difficulties on the building site as attested by archive documents conserved in Venice and in Turin. The civic centre concentrates the complexity of the whole project in one element, a mushroom-form column used to characterized the main square. In spite of problems with realisation and maintenance, this place still contributes to the identification of the inhabitants of Falchera with their neighbourhood.

\section{Giorgia Sala}

University IUAV of Venice

KEY WORDS

Nicolas Moucheront 


\section{INTRODUCTION}

The Falchera estate in Turin is the expression of a specific concept of city developed within the Comunità movement of Adriano Olivetti after World War II. Many architects and planners were part of this cultural environment and shared a common aspiration: to rebuild the society not only physically but also morally. Although Falchera has remained an isolated and circumscribed experience in the Italian reconstruction, it is a representative example of the idea of city developed just after the war. To understand the concept of 'organic neighbourhood' in its formal and methodological meanings, two different but complementary points of view are adopted. On the one hand, the housing estate is studied as an urban form, which coordinates urban and architectural detail scales. On the other hand, Falchera is approached as the main protagonist of a communication strategy within consolidated urban models.

The architect Giovanni Astengo (1915-1990), leader of the project team, did not only lead the conception of Falchera. He also directed the reception of the project, publishing two important articles about Falchera in 1951 and 1954. The few historians who integrate this study case in their overview on post-war Italian architecture all discuss the interpretation given by Astengo of his own realisation. Manfredo Tafuri underlines the "forced naturalness" of this organic low-tech project, while Carlo Olmo insists on the 'unsolved relationship between innovation and tradition.' ${ }^{2}$ This last attempt refers to several constructive experiments in Piedmont of which the mushroom-form pillars of the Falchera civic centre are a symptomatic example. However, as it was built late and abandoned before completion, this part of the project has never been published nor studied.

It is, in consequence, necessary to complete the existing bibliography with original documentation in order to understand the different scales of the project. The archive of Astengo's studio conserved in the Archivio Progetti of the IUAV university in Venice, includes drawings, study materials and photographs. We have also read all the conserved letters received by Astengo in his studio during the ten years that the project lasted. ${ }^{3}$ The material conserved by the Territorial Housing Agency (ATC) in Turin gives a broader view on the work of all architects involved in the project and on their relationships with the various building firms and the INA-Casa central administration. The final drawings of the project, as well as extensive documentation related to the maintenance of the complex is kept in this estate archive. We focus on the documents related to the completion of the civic centre, sparsely documented in Venice. ${ }^{4}$ 
For studying the architectural culture of the architects of Falchera, the record of magazines Astengo had subscribed to, as well as his personal library, conserved at the IUAV, have been valuable. ${ }^{5}$ The books' provenance and some autograph inscriptions, coupled with the correspondence preserved in the Archivio Progetti, enable us to reconstruct a part of Astengo's international network of contacts. His relationships with the French architect and urban planner Robert Auzelle could also be explored thanks to the correspondence conserved in the Institut Francais d'Architecture in Paris. ${ }^{6}$ Giovanni Astengo was not only an architect, but also a teacher, and delivered many lectures, as well as participating in exhibitions and conventions. He was also chief-editor of the magazine Urbanistica. How did media affect the design strategies of Falchera?

\section{THE GENESIS OF FALCHERA}

The project team for Falchera met at the end of World War II. All designers were members of a group of modernist architects, created in 1945 in honour of Giuseppe Pagano, ex-director of the magazine Casabella and important leader of the anti-fascist resistance in Lombardy, who died in deportation. Many innovative concepts for urban design were discussed underground during the war, in order to prepare a new society. A foreign concept as the linear city is applied to the Po valley by the ABRR group composed by Astengo, Mario Bianco, Nello Renacco and Aldo Rizzotti. The Padan productive strip project (nastro produttivo padano) was intended to connect Turin with other urban centres through an industrial linear city.

It is possible to trace the source of this well-defined urban model. First proposed in Spain by Arturo Soria y Mata, who built a linear suburb for Madrid in the second half of the nineteenth century, this model was further developed in the USSR during the twenties by Nikolay Milyutin, referencing the Fordist assembly line. The linear city is composed of alternating parallel strips of industrial buildings, housing and linear parks associated to a river, a canal, or any sort of transport infrastructure. This Spanish urban model developed in the USSR returned to Europe in the thirties, through Germany, and inspired many studies for the contemporary city.

For example, Astengo had in his library a copy, offered to him by Bianco, of The new city, published by Hilberseimer in 1944.7 This title is quoted by Astengo, Renacco and Rizzotti in an essay they wrote together in 1944, House and work in the city of tomorrow. ${ }^{8}$ Dealing with the relationships between housing and working spaces, the bibliographical references of this essay are very eclectic. 
Utopian projects by Ebenezer Howard or Tony Garnier are quoted, but the structure of the argumentation is much inspired by historical books, such as those written by Lewis Mumford on urban development, or by Amintore Fanfani on economy.

More so than this theoretical essay, which was never published, it is the Padan productive strip which first sparked interest towards Astengo's and his fellows' work. In 1945, the National Institute of Urban planning (INU) put them in charge to devise a regional plan for the Piedmont, which was presented in 1947 during the International exhibition of urban planning and housing in Paris. As brief as this exhibition may have been, it arrived at a key moment for the postwar rebuilding of Europe. The Marshall plan, imagined to convert the American war economy and to contain communist electoral successes in France and Italy, was in discussion in Paris at the same moment. Few as aware as Astengo of the parallel between these two events.

Last summer in the Grand Palais, two important European events took place in the same moment: while the main room and the garden hosted the international exhibition of urban planning and housing, in the office on the Champs-Elysées, took place economical meetings related to the Marshall plan. A coincidence and a cohabitation, but unfortunately not a correlation, as it would have been more logical and efficient for both events. ${ }^{9}$

In the whole article, published in a newspaper as part of an economical chronicle, Astengo defends a coordination between economical development and urban planning. This ideal of coordination expressed metaphorically in the project of the Padan productive strip, is also related to the parallel professional careers Astengo tried to follow during the 1950s. He was, at the same time, taking over his father's firm for kitchen furniture, as well as developing with Bianco and the engineer Ceratto a prefabricated metal house called the Casa ABC. In spite of promoting the patent in The Architectural Review, and, after the Paris exhibition, in Techniques et Architecture ${ }^{10}$, not a single house was built and the furniture business would eventually collapse.

When Astengo advised a client to read Max Bill and Joseph Abraham's books about prefabrication, reactions were not enthusiastic as testified by few letters. Heavy prefabrication intended as an 'industrialisation of building' had little following in the Italy of $1948 .{ }^{11}$ In Italy, the electoral victory of the Christian Democracy (DC) over the Socialist Union led to the development of architectural solutions totally different from the French grands ensembles in Italy. 
The Fanfani law approved in 1949 led to the creation of the INA-Casa Program, in order to resolve the two most urgent national issues, home and work. The building of new houses was seen as a means to increasing employment. As a consequence, building contracts promoted traditional construction firms, employing a numerous non-skilled workforce. This trend had consequences on the Falchera project and on the management of the building site.

\section{AN INA-CASA PROJECT}

In order to ensure spatial qualities and fine standards of living in each funded estate, the INA-Casa direction published several guides on housing complex planning. The authors of the guides, who were recruited in Rome by INA-Casa, encouraged architects to make reference to local constructive traditions. They proposed at the same time schematic plan solutions and normative dimensions, illustrated by Italian and international realisations. The intent was to invent an architectural language, which may fit within popular reality, creating a spontaneous and genuine environment.

The house must contribute to the formation of the urban environment. [Architects] would keep in mind the spiritual and material needs of people, of the real people and not of an abstract being: people don't love and don't understand the indefinite and monotonous repetitions of the same type of dwelling, where it is not possible to distinguish one's own among others without the help of a number; they don't like the checkerboard urban plans but prefer cosy environments with a certain spatial dynamic. ${ }^{12}$

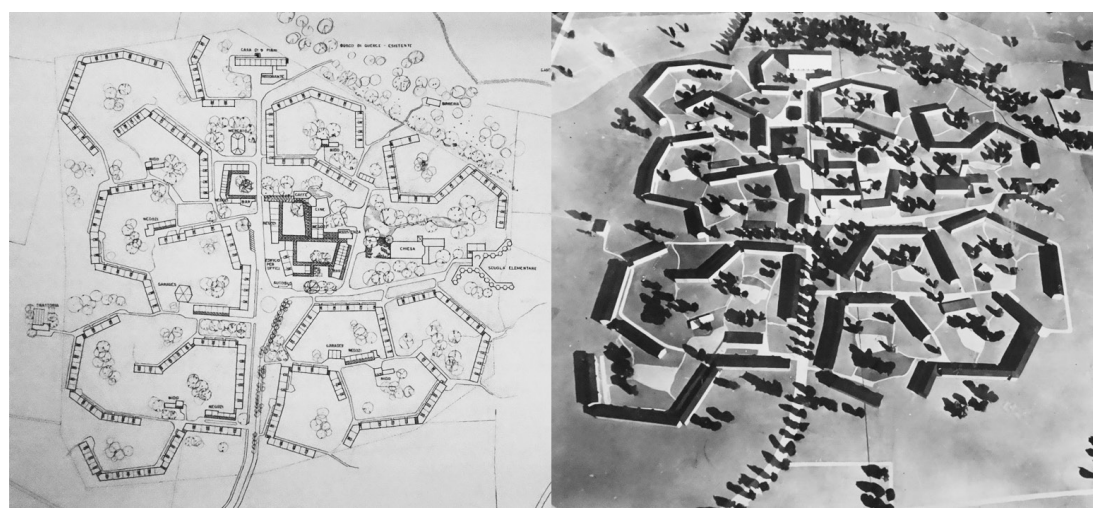

Figure 1. General layout and model of Falchera, first version, 1951. Source: Archivio Progetti (AP), Fondo Giovanni Astengo (FGA), DIS/08/04-38247 and FOT 025. 
The imagery of Italian neorealism in literature and cinema, as exemplified by writers such as Vittorini or Pavese and directors as Rossellini or De Sica, aspires to the same atmosphere as these architectural prescriptions. ${ }^{13}$ Some housing estates as the Tiburtino in Rome by Quaroni and Ridolfi, or the village La Martella in Matera by Quaroni, Gorio, Lugli, Valori and Agati, as well as the San Basilio district in Rome by Fiorentino and Boselli are promoted by this literature and some of these films.

The Falchera project in Turin refers to the same imagery in order to create an organic community in a rural area. This name derives from the Falchero brothers, owners of an eighteenth-century farmhouse which existed in the surroundings. The estate purchased by the INA-Casa in 1950 is more than 300,000 square meters. It is located in the north side of the city, near an important axis of communication and at some distance from two planned industrial areas. The INA-Casa called Astengo to lead the project team. He worked with ABRR fellows Renacco and Rizzotti and two other architects from Turin, Sandro Molli Boffa and Mario Passanti. This was indeed the first INA-Casa realisation in the city of Turin, and one of the first to be approved in Italy.

The masterplan envisioned a self-sufficient satellite unit, with its own collective facilities. Falchera stands indeed at the margin of the city and needs a functional and formal autonomous structure:

Peripheral location is not a problem for collective housing if each unit has a truly autonomous character. Arising in unbuilt areas, free from the meshes of pre-existing old regulatory plans, they may be characterised by the architects with a greater freedom in the implementation. Furthermore, being detached from the town, they are not directly in contact with the anonymous building of the suburbs. ${ }^{14}$

The urban planning concept anticipated an architectural definition of public spaces. These two scales of intervention are indeed coordinated by Astengo. At an urban scale, the extensive settlement and the shaping of public spaces are defined by the collective of architects. A polygon resulting from this urban design is to be articulated by each architect when designing the housing plans. However, a common architectural vocabulary ensures the formal coherence of these singular projects: the choice of 'domestic' typologies refers to local constructive traditions. Rules for the dimensions and orientations of each living space were decided collectively. 


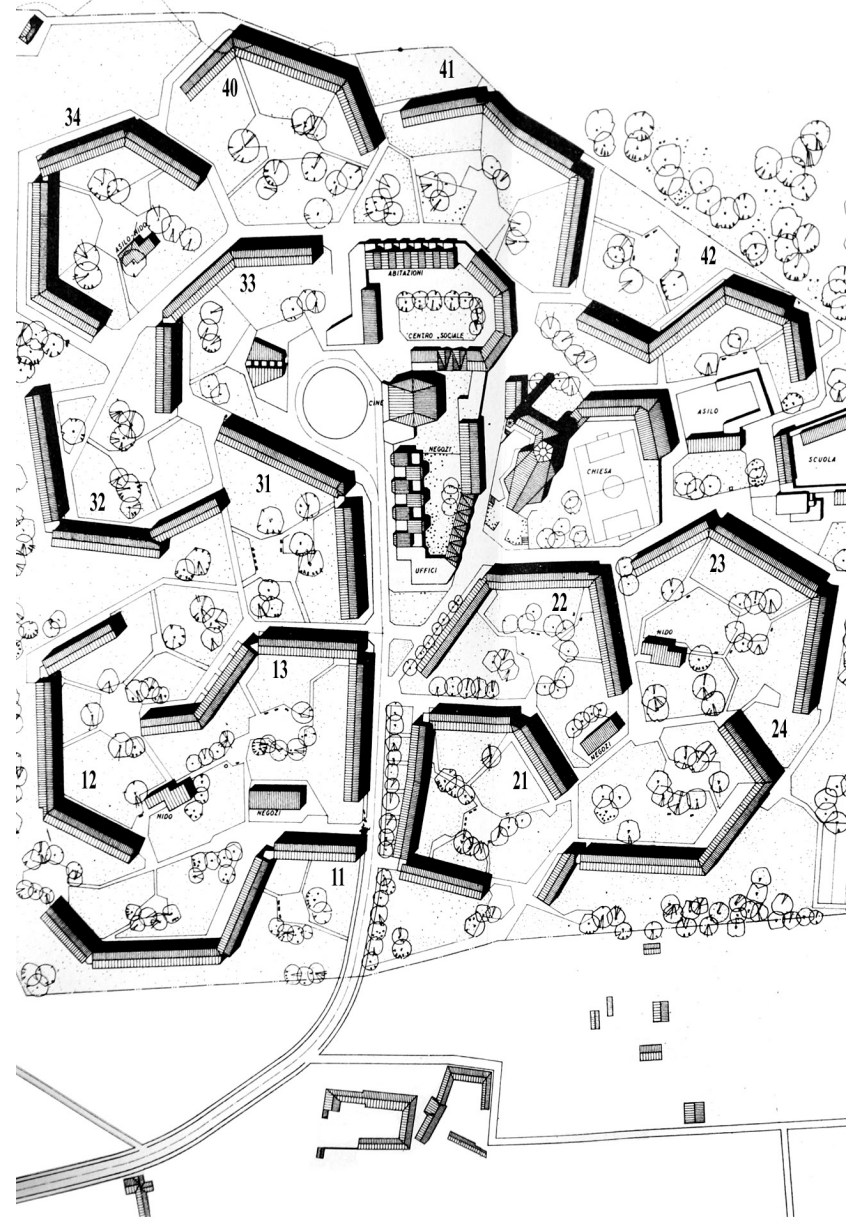

Figure 2. General layout of Falchera (with number of residential buildings), second version, 1954. Source: AP, FGA, DIS/08/05-38267.

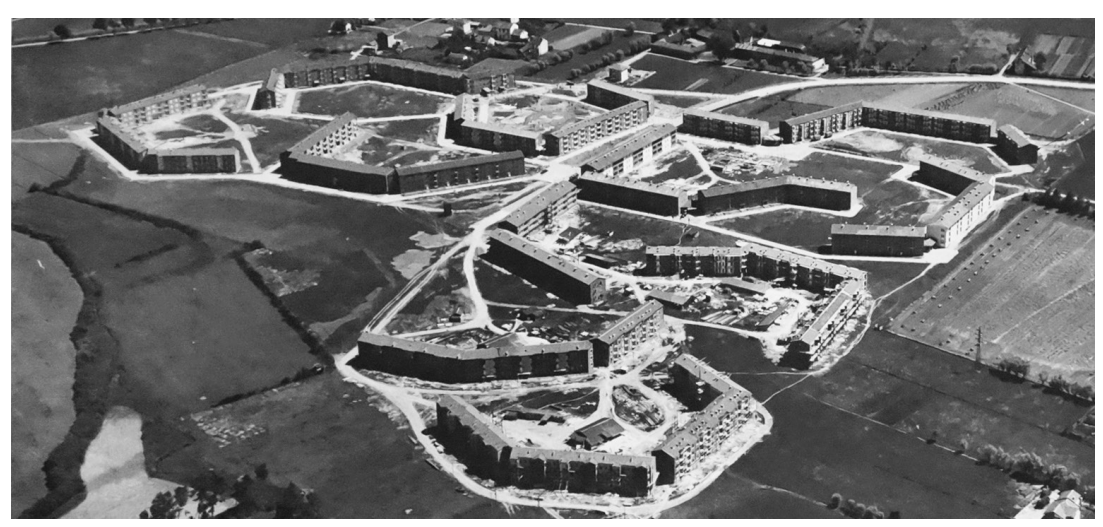

Figure 3. Aerial view of Falchera's building site, 1954. Source: AP, FGA, FOT 025. 
Falchera's masterplan is based on an organic network. The views from each apartment converge on a common green space in order to create neighbourhood relationships. Each U-shaped close ${ }^{15}$ is defined by residential buildings arranged around little shops or day nurseries (which were later transformed in garages). Two well-defined sectors, of four U-shaped closes each, are built on both sides of a tree-lined avenue connecting Falchera with the existing road network. This corresponds to the first phase of construction of Falchera, between 1951 and 1954. The avenue as the trunk of a tree, leads to the civic centre, 'the heart of community life', built after 1954. It groups various facilities, such as a church, a school and a store, addressing the whole of Falchera. (Fig. 2)

The tree-like road system passes along the service and staircase side of each building. A secondary network of pedestrian paths enters the closes. It connects one green space to another, passing through the junction points of the U-shaped closes. The project aims at total permeability of public spaces but the first inhabitants erected gates and walls to make each close pertaining only to the residents of the respective precint.

At the end of the tree-lined avenue, a higher building for shop-tenders' habitations was drawn in the 1951 version of the project, but this element disappears in the 1954 version. In order to create 'another kind of city different from the chaotic periphery', all the neighbourhood is composed of three-story buildings, freely associated. ${ }^{16} \mathrm{~A}$ broken concave and convex line of U-shaped closes translates spatially the ideal of a life in small scale neighbourhoods, in contact with a natural environment and at the same time gathered around a centre for community life. The utopian value of this urban form can be understood only inside the specific context.

\section{FALCHERA AND THE MAGAZINE URBANISTICA}

From 1949, Astengo was a member of the Directive Council of the INU which trusted him with the editing of its official magazine, Urbanistica. Directed by Adriano Olivetti, the magazine had numerous press correspondents all over Italy and abroad. The graphic design was curated by Egidio Bonfante, who also worked for the magazine Comunità. Astengo and Bonfante were both curators of the urban planning section of the ninth Milan Triennal during Spring 1951. It is the first public presentation of the Falchera project whose plan had just been delivered and probably approved by the INA-Casa. ${ }^{17}$

In this exhibition, an introductory section presents large format photographs describing the hard life conditions in old city centres, such as promiscuity, 
darkness and congestion. At the end of that section, entering a large and luminous hall, there is the vision of the city of tomorrow. A panel on the left wall presents more than ten projects awaiting approval by the INA-Casa. Two large models, of the San Marco village in Venezia-Mestre, and of Falchera in Turin, are presented at the centre of the room. ${ }^{18}$

In the precise point where the dark corridor of the old city opens into the large room of the modern city, a little model of a social housing project in Troyes, France is displayed. This is an emergency housing unit where inhabitants of the medieval city centre of Troyes were sheltered while a new city centre was under construction. Following a survey carried out by social workers, newly-built apartments were attributed to each family. This programme interested Astengo, who wrote to the research unit of the French Urban planning and Reconstruction Ministry (MRU) for permission to exhibit documents on the project in Milan.

This office was headed by Robert Auzelle, organiser of the 1947 exhibition, teacher in the Paris' Institut d'urbanisme and French correspondent for Urbanistica for $1949 .{ }^{19}$ In the ninth issue of the magazine, Auzelle details his social survey method, presenting the sheet form prepared to analyze the tenants' way of living in Troyes and elsewhere. He also presents the quartier de la Plaine, which he was building in Clamart at the time. ${ }^{20}$ Complete documentation on this grand ensemble was ready for the 1951 exhibition. Probably due to a lack of space, the project was nevertheless only published the following year. The correspondence between Astengo and Auzelle testifies however that while finishing the masterplan for Falchera, Astengo had already received the drawings for the quartier de la Plaine. ${ }^{21}$

Both projects share formal traits with Scandinavian housing estates. The first images of Gröndal and Danvikslippan were published in Italy to illustrate an article by Auzelle in Urbanistica No. 2. ${ }^{22}$ The Swedish architects Backström and Reinius were already known in Italy through the Foundation Elving, published in 1941 by Casabella. The brick walls of block No. 22 in Falchera, designed by Astengo, are folded in the same manner as those of the Elving Foundation. The three-story buildings and the sloping roofs of Falchera are also reminiscent of two Danish public housing estates: Bisperparken and Sudparken in Copenhagen. These references are reminded in an INA-Casa guide ${ }^{23}$ which reprinted photographs once published in L'architecture d'aujourd'hui ${ }^{24}$. The same images were used in the XIII International Congress for Housing and Town Planning proceedings, conserved by Astengo in his personal library. ${ }^{25}$ The Danish section of the 1947 International exhibition of urban planning and housing in Paris had been a great success. 
Astengo started travelling abroad only in the fifties, for economical reasons, and it is probably only through publications and personal exchanges with francophone correspondents, such as Auzelle, that he knew of these foreign experiments. For a 'serious study' on urban planning, it is necessary to gather maps at the same scale, in order to compare various situations. This was the purpose of the Cahiers d'urbanisme by Robert Auzelle and Ivan Jankovic, diffused in Italy by Astengo through Urbanistica. ${ }^{26}$ After the resignation of Adriano Olivetti in 1952, Astengo was promoted the director of the Italian magazine and started publishing monographic issues dedicated each to one city. Under his direction, Urbanistica slightly changed vocation, from a communication organ of the INU to a documentary compendium on urban design.

The coloured plans of Scandinavian estates published in the magazine were fully redrawn for the occasion. This editorial work proceeded in parallel with the design process of Falchera. Non-orthogonal geometries continued to influence Astengo, Renacco and Rizzotti throughout the fifties. They also realised together the Lucento estate in Turin and produced one of the first proposals for the via dei Filosofi in Perugia, also featuring obtuse angles. ${ }^{27}$ The lesson of Swedish architecture is adapted to an un-horizontal topography thanks to a public balcony at mid-height. This element might also have been influenced by certain London estates and a few projects for Algiers, published in British and French architecture magazines.

Leafing through a magazine about architecture, it is possible to have an idea of the visual culture of architects in a certain moment. Gianfranco Fasana who redrew the Swedish estates' plans published in the fifth issue of Urbanistica was associated with the Falchera project from 1952. The formative period of this young architect included copious redrawing of references. However, it is not only a common background that created cohesion in the project team. Few common rules were defined collectively at the beginning, integrating the requirements of INA-Casa. All buildings had to have face brick walls, a similar kind of joinery, the same number of floors and the same roofing type. Within these rules, each architect was free to propose variations.

\section{BUILDING FALCHERA}

The construction of the two southern sectors of Falchera started in 1952. Gianfranco Fasana with Gino Becker, Augusto Romano and Ettore Sottsass Sr. joined the design team. The building site organisation was not centralised, but organic as the project. Each architect was responsible for a sector of the general layout and would design his buildings following the provisions recorded in 


\begin{tabular}{|c|c|c|c|c|c|}
\hline $\begin{array}{l}\text { no. } \\
\text { block }\end{array}$ & ARCHITECTS & $\begin{array}{l}\text { CONTRACTING } \\
\text { AUTHORITY }\end{array}$ & $\begin{array}{l}\text { Works delivery } \\
\text { date }\end{array}$ & $\begin{array}{l}\text { Works completion } \\
\text { date }\end{array}$ & FIRM \\
\hline 11 & E. Sottsass sr. & Istituto Previdenza Sociale & 15 April 1952 & 21 November 1953 & Martelli \\
\hline 12 & S. Molli Boffa & Istituto Case Popolari & 18 August 1952 & 26 June 1953 & Bettoli \\
\hline 13 & M. Passanti & $\begin{array}{l}\text { Amministrazione pro- } \\
\text { vinciale }\end{array}$ & 20 May 1952 & 05 June 1954 & Miccone \\
\hline 21 & N. Renacco & Commune di Torino & 19 August 1952 & 02 December 1953 & Martelli \\
\hline 22 & G. Astengo & Commune di Torino & 19 August 1952 & 26 June 1954 & Coop. di Imola \\
\hline 23 & A. Rizzotti & Commune di Torino & 19 August 1952 & 03 December 1953 & Miccone \\
\hline 24 & $\begin{array}{l}\text { G. Becker - A. } \\
\text { Romano }\end{array}$ & Commune di Torino & 19 August 1952 & 09 July 1953 & Accati \\
\hline 31 & $\begin{array}{l}\text { M. Passanti - P. } \\
\text { Perona }\end{array}$ & Istituto Case Popolari & 06 June 1953 & 30 May 1955 & Broggi e Peraldo \\
\hline 32 & $\begin{array}{l}\text { G. Becker - G. } \\
\text { Fasana }\end{array}$ & Istituto Case Popolari & 06 June 1953 & 30 May 1955 & Broggi e Peraldo \\
\hline 33 & $\begin{array}{l}\text { F. Grassi - N. } \\
\text { Renacco }\end{array}$ & Istituto Case Popolari & 06 June 1953 & 30 May 1955 & Castaldi e Serra \\
\hline 34 & $\begin{array}{l}\text { A. Rizzotti - } \\
\text { M. Oreglia }\end{array}$ & Istituto Case Popolari & 06 June 1953 & 30 May 1955 & Castaldi e Serra \\
\hline $40 / \mathrm{A}$ & $\begin{array}{l}\text { G. Gigli - G. } \\
\text { Astengo }\end{array}$ & $\begin{array}{l}\text { Ministero Agricoltura e } \\
\text { Foreste }\end{array}$ & 10 April 1956 & 22 September 1957 & $\begin{array}{l}\text { Generale Costruzion } \\
\text { COIMAS }\end{array}$ \\
\hline $40 / B$ & $\begin{array}{l}\text { G. Gigli - } \\
\text { Giovanni } \\
\text { Astengo }\end{array}$ & $\begin{array}{l}\text { Ministero Pubblica } \\
\text { istruzione }\end{array}$ & 27 August 1956 & 21 August 1957 & $\begin{array}{l}\text { Generale Costruzion } \\
\text { COIMAS }\end{array}$ \\
\hline 41 & $\begin{array}{l}\text { G. Astengo - } \\
\text { G. Becker - M. } \\
\text { Oreglia - A. } \\
\text { Romano }\end{array}$ & Istituto Case Popolari & 20 April 1957 & 11 September 1958 & $\begin{array}{l}\text { Boggio Marzet e } \\
\text { Grometto }\end{array}$ \\
\hline 42 & $\begin{array}{l}\text { G. Astengo - } \\
\text { G. Becker - M. } \\
\text { Oreglia - A. } \\
\text { Romano }\end{array}$ & Istituto Case Popolari & 20 April 1957 & 14 June 1958 & $\begin{array}{l}\text { Boggio Marzet e } \\
\text { Grometto }\end{array}$ \\
\hline
\end{tabular}

Figure 4. Table of phases of construction of residential buildings.
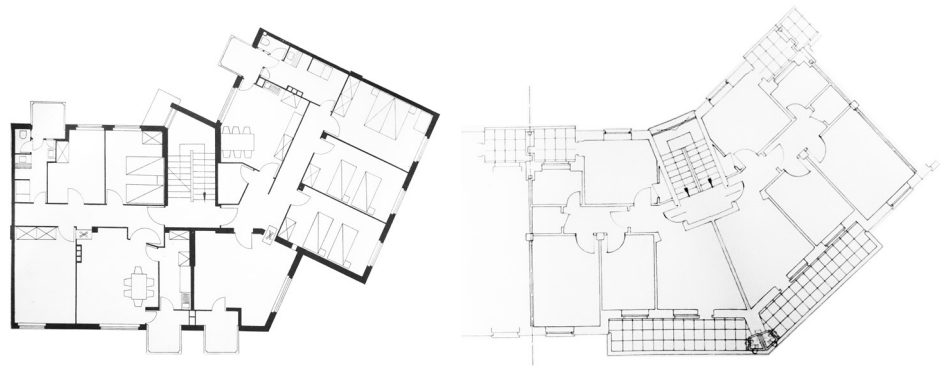

Figure 5. Two examples of "junction solutions": block 11 (Sottsass) and block 13 (Passanti). Source: AP, FGA, DIS/07/1 and DIS/07/3.

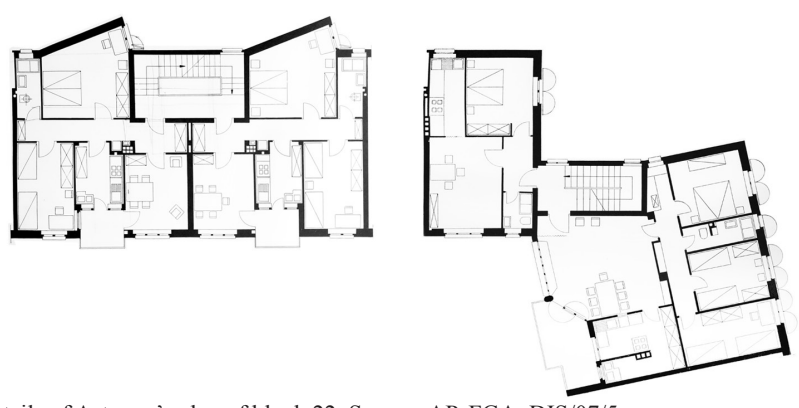

Figure 6. Details of Astengo's plan of block 22. Source: AP, FGA, DIS/07/5. 
the General technical specification. Works proceeded in parallel in each sector with a different building firm. Around its own barracks, each housing unit grew as an autonomous village. In this way, building contracts were accessible to local craft firms. As recommended by the INA-Casa, low-mechanisation techniques requiring a numerous workforce were adopted. The foundations were cast in reinforced concrete conglomerate; the walls were made of solid bricks with reinforced concrete pillars in the angles; the floors are in concrete and masonry slabs; the roof is supported by wooden trusses. ${ }^{28}$ These techniques are totally different from the prefabricated systems Astengo had researched between about 1944 and 1946 for his ABC patent. Nevertheless, unified doors and window-frames were adopted and the approach remains rationalist. The studies on buildings' orientation published in 1946 by Metron ${ }^{29}$ were not abandoned but developed in the same direction pursued by Auzelle in France ${ }^{30}$. It is an attempt to ensure the best possible orientation for each apartment, within traditional urban forms.

A specific ratio between the surface of each apartment and the length of its facade is defined, and a coefficient is attributed to each orientation. It entails that a building whose main facade is opened on the south can be deeper than a south-east or south-west oriented building. As a consequence, all apartments are different. To arrange the angles of each U-shaped close, architects developed different strategies. Block No. 41, realised in the second phase of construction, presents an accomplished solution: a wing is associated to another one in a continuous way, through a specific apartment adapted to each different angle. Ettore Sottsass Sr., in block No. 11, also uses the stairs as a junction element and Mario Passanti in block No. 13 aligns it on the bisector of the angle in order to serve two symmetrical apartments. (Fig. 5) A simpler solution consists in separating each wing as Aldo Rizzotti does in block No. 23. The enclosing of each court is ensured by a portico on the ground floor.

Block No. 22, built by Astengo between 1952 and 1954 (Fig. 6), is a complete assortment of differing apartment typologies. Units with one, two or three bedrooms open either on one side of the building, or on two opposite sides. The organisation of apartments is adapted to the general orientation of buildings and facade detailing adapts the plan to the specific orientation. The living room always opens on the common green space of the close. A loggia, more or less deep, adjusts the relationships between inside and outside. For example, window frames are oriented for glass to be always perpendicular to sun rays. Bedrooms are always placed on the opposite side of the building to where common areas are, and have smaller windows. To give some movement to the north front of the block No. 22, Astengo 'folds' the brick walls in order to open the room laterally. It creates an elegant pattern of light and shadow, whereas the opposite 
south front is designed as an alternation of loggias and horizontal windows. This disposition lets the sunlight enter deep into the apartments during the winter months, while limiting it when the sun is high during summer.

\section{A NEO REALIST NEIGHBOURHOOD}

In 1954, Astengo published an important booklet of forty pages on Falchera in the Metron magazine. ${ }^{31}$ Photographs, drawings and diagrams closely associate with the text, contribute to an efficient rhetoric by means of elegant graphic design. The iconography published in this issue is reproduced in most books as if it represented the definitive project. ${ }^{32}$ In reality, important modifications were made after 1954, during the construction of the Civic Centre. With this publication, Astengo builds a seductive narrative around Falchera, which was picked up by most historiographers. His intent is to portray Falchera as an exemplary INA-Casa district, a symbol of the organic neighbourhood promoted by the agency.

The single recognised source of inspiration are the rustici of Stupinigi. These rustic brick dependencies of the seventeenth century royal palace of Stupinigi are presented as the unique architectural reference. There is not a single mention of Swedish architecture. The fortunate proximity of the organic masterpiece of Juvarra, cited as an example for its peculiar relationship with landscape, allows Astengo to exalt the qualities of vernacular architecture. The rural context of Falchera is presented through photographs of the site before and during building works.

The layout of the pages dedicated to Falchera is very striking. Perfectly controlled black and white photographs dialogue with maps, sections and brief captions. The human presence is of significance, and a few coloured photographs are also inserted. The photo retouching doesn't hide the nude expanses around the buildings, where gardens would be planted only in the sixties. It seems, on the contrary, that it is this transitional phase that is emphasised in the photographs, featuring children playing on the lawns of their district, still under construction.

The families arriving in Falchera were in most of the cases migrants from southern Italy. They had much more children than expected, and, to aggravate the situation, the school had not been built yet. In September 1954, the City of Turin funded in emergency the construction of prefabricated wood barracks to enroll all these children in school. During construction of the church, mass was celebrated in the hall of a condominium. Residents would lament the lack of 
public facilities and transport infrastructure to reach the city centre. Falchera is nowadays at the end of a tramway line but at least half an hour is still necessary to reach the centre of Turin and the Porta Palazzo market.

Only in January 1954, the INA-Casa direction decided to complete the Falchera unit with a civic centre including the necessary collective services, in order to provide for an 'organic integration of the building complex'. The direction invited the Autonomous Institute for Popular Housing (IACP), 'to turn to the professionals who have collaborated in the urban planning and design of the complex'. ${ }^{33}$ The relationships between architects, estates and building companies are precisely detailed in the Fanfani law, but the realisation of a civic centre involves many other actors: the bishop for the church, the mayor for the school and public spaces, the telecommunications ministry for the post office and so forth. Moreover, INA-Casa usually financed public social housing, but the shops of the civic centre were to be sold to the tenders. The idea proposed by architects to associate an accommodation to each shop in order to attract shoptenders had little success at the beginning. For a long time shops would stay unoccupied as nobody wanted to invest in a public housing estate.

\section{THE CIVIC CENTRE OF FALCHERA}

To build a city, the little community of the INA-Casa had to open up to civil society and architects had to set out and convince members of the public. This was probably the main function of the publication in Metron, which does not present an achievement but, on the contrary, introduces the hardest phase of the project. Astengo designed two main proposals: a 'two-squares' solution, based on two open spaces connected one to the other by a system of porticoes, and a 'unique square' solution, with the church in the centre and all the public facilities around it. (Fig. 7)

The final project develops this last proposal, adding a two-floor building for shops and private habitations to be sold to shop-tenders, designed by Rizzotti and Fasana. Astengo built the post office and the bank, the clinic and the pharmacy, the emporium-restaurant-café. He also designed a cinema, behind the clinic, which was never built, and a garage, partially built. Furthermore, he designed the portico connecting the buildings around a paved square, as well as a fountain and a few stands for an open-air market, also never built. Renacco designed the church on the south side of the square, and Rizzotti the social services centre. Finally, the elementary school, a part of the square, was slightly moved to the east and designed by Molli Boffa. The construction of the buildings of the civic centre started in 1959, five years after the settling of the first inhabitants. (Fig. 8) 


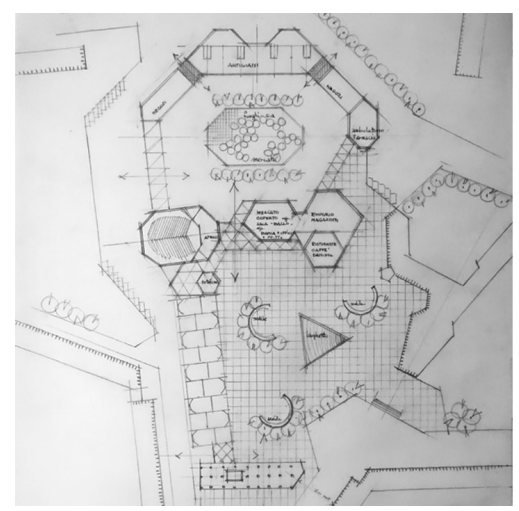

Figure 7. Studies for the centre of Falchera, 1955 Source: AP, FGA, DIS/08/08-38250 and DIS/08/0738249

Figure 8. General layout of the centre of Falchera, 1956. Source: AP, FGA, DIS/08/13-38254.
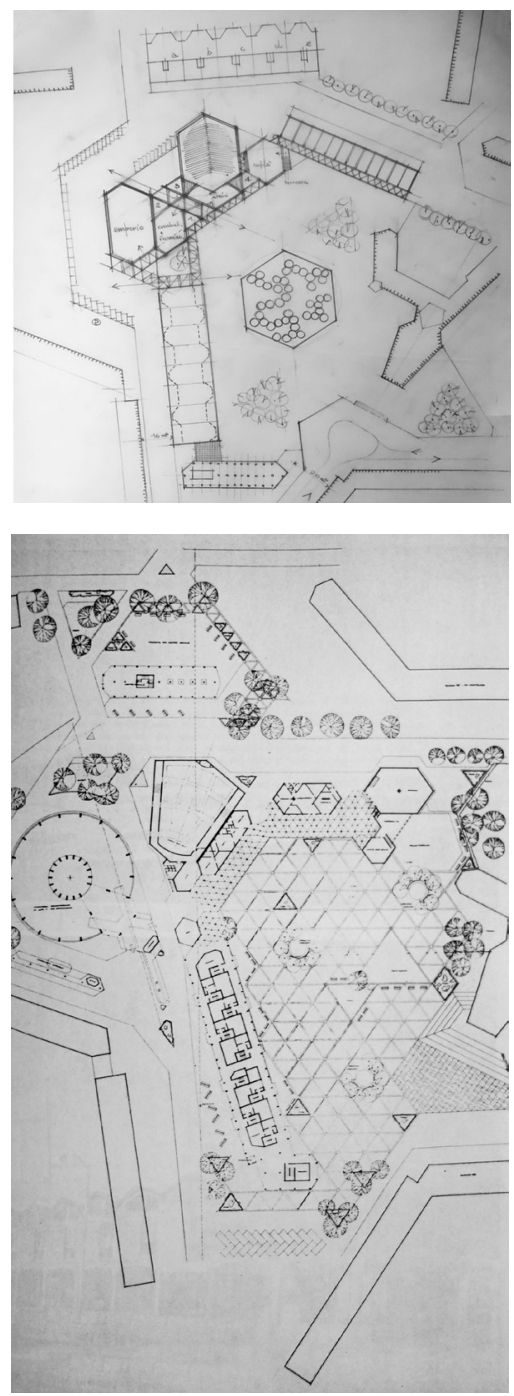
The buildings of the civic centre by Astengo are formally characterised by specific materials and uncommon geometries. As for residential buildings, walls are made of bricks, with glass blocks inserted in the masonry. Hexagonshaped windows are opened in the concrete crowning of some buildings. Each hexagon derives from a grid with a triangular pattern. This grid also affects the plan organisation of the interior spaces: served main rooms are articulated by hexagonal service spaces. Structural elements and constructive details respect the same rules: hexagonal window-frames characterise elevations and many beams have a hexagonal section.

This redundant hexagonal pattern, both in plan and in elevation, is characteristic of the second phase of Falchera's construction. At the same moment, a hexagon appeared on the front cover of the magazine Urbanistica. ${ }^{34}$ These connections between architecture and visual communication can possibly be explained by the involvement of Astengo as chief editor and from 1953 as director of Urbanistica. He also delivered many lectures in Italy and abroad, always presenting his own projects with slide images. It is a kind of communication quite innovative for the time: in the fifties, most lessons at university and public lectures did not have any image support. The abstract concepts Astengo tried to communicate, as the idea of Comunità, gain a formal identity through the images of his own architectural projects, that he showed in public.

The hexagonal pattern is reminiscent of the geometries developed by Frank Lloyd Wright in his prairie houses, well-known in Italy thanks to the promotion of the American architect carried out by Bruno Zevi. Specifically, two buildings realised in the mid-fifties for Olivetti in Ivrea use this pattern: the social services headquarters of the firm by Luigi Figini and Gino Pollini, and Ignazio Gardella's Olivetti canteen. In 1958, with the candidature of Adriano Olivetti for legislative, the Comunità movement entered politics in order to create a third force between Cristian Democracy (DC) and the Communist party. ${ }^{35}$ In parallel, it is possible to observe an emphatic formalism in realisations promoted by the Olivetti firm, both in graphic design and in architecture. As a logo, the hexagon became a symbol of the ideals of Comunità.

Astengo, the leader of the Turin headquarters of the movement, is also intellectually linked to Olivetti by a common interest for the development of southern Italy. With Giuseppe Samonà, he planned various neighbourhoods in the Sila Valley, Calabria. In 1955 he designed a detailed project for a services centre in San Leonardo di Cutro. Plans and sections for this unbuilt project are much more detailed than those conserved for the Falchera civic centre. There is a similar formal inspiration for the two projects, drafted in the same period, but Astengo gradually lost control on detail conception while building Falchera. 


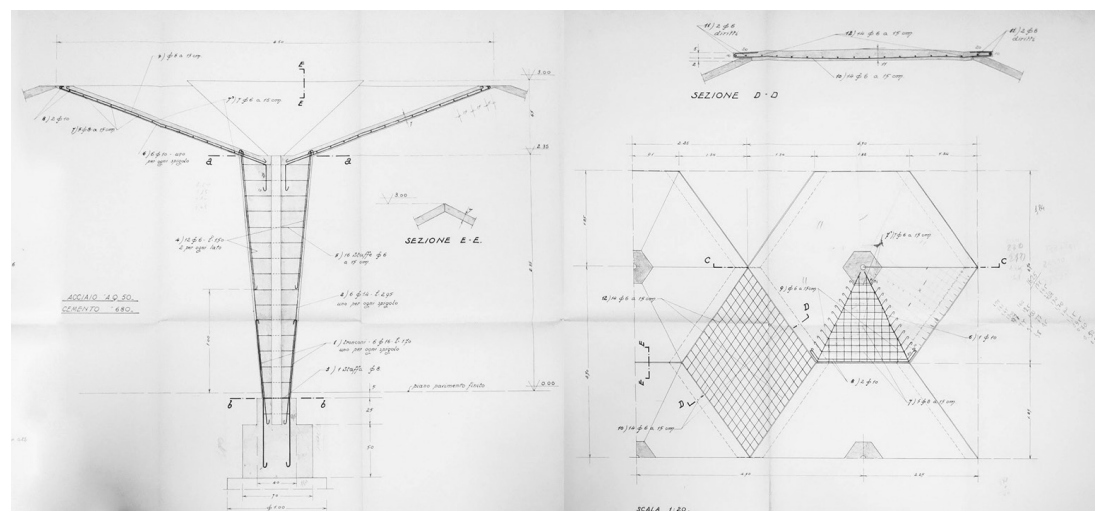

Figure 9. Construction drawing of mushroom-form pillars, 1959. Source: AP, FGA.

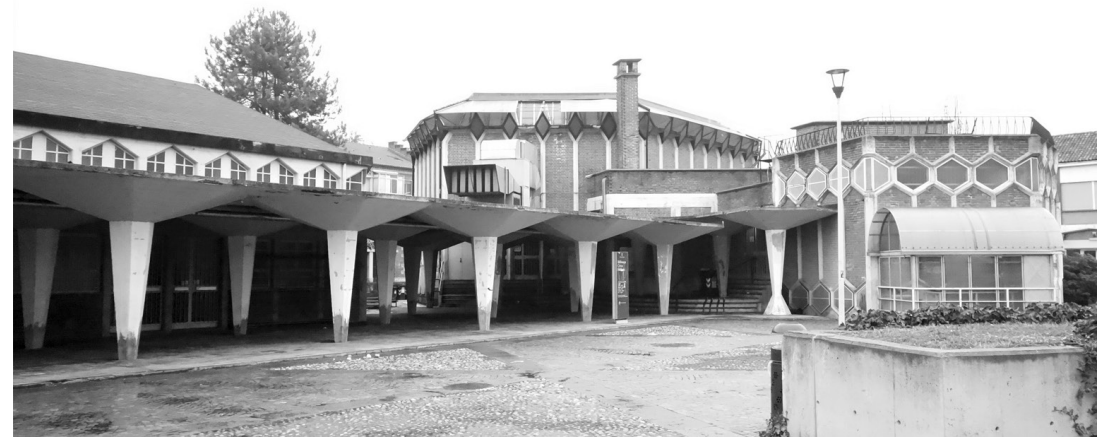

Figure 10. Contemporary photo of the center of Falchera, authors' photo. 
The portico of Falchera illustrates the difficult passage from an aggregation concept to a structural system. The mushroom-form pillars are a threedimensional synthesis of the social and economical dimensions of the project. They give a human scale to a public space that could organically grow and at the same time constitute a low technology constructive experiment. This solution was developed by the engineering studio of Eugenio Miccone and his brother, who also worked personally in the construction firm which built the entire civic centre. The concrete pillars were cast inside special wooden formworks, made on-site: nothing is prefabricated in this modular structure. Each mushroom should ideally have been independent. In drawings they hardly touch one another by one side or on a corner, and a rhomboid-shaped dry-assembled panel closes the system. The concept of organic growth is developed to the scale of detailing. Astengo obsessively tried to respect this method from the beginning to the end of the project. Nevertheless, an examination of the completed structure reveals that the whole portico was actually cast in a single pouring. The building firm could modify the structure 'only with the clear advice of the architect' which means that Astengo had probably approved this modification of the project. ${ }^{36}$

The structural solution of the mushroom-form pillars is characteristic of a theoretical studio approach to construction. From 1944, Astengo chaired the Constructive Elements lessons in the Turin Politecnico. Even if he is more famous for his contribution to the teaching of urban planning, having created a pianificazione department at the IUAV in Venice, he was really involved in this first teaching activity. He promoted for example the inclusion of a sample collection of construction materials at the library of the Turin Politecnico. The patenting for the Casa $\mathrm{ABC}$ and the Cutro project attest an evolution of his conception of construction between the mid-forties and the mid-fifties. It is no more a totally industrial solution which is proposed in Calabria, but a hybrid between vernacular and industrialised techniques. For example, transom beams, doorjambs and window sills realised in precast concrete also serve as formwork for a rubble masonry wall. The metallic structure for the portico of Cutro is also of great interest. It is not a 'mushroom-form' structure as realised in the second phase of Falchera but a simple tiled pitched roof, bearing on wood planks and metallic beams. The detail of the junction between tie rods and the folded sheet metal at the top of each pilaster can be read as a modern column capital.

During the first project phases of Falchera, such original constructive experiments were developed in each sector, with each architect creating his own vocabulary. Astengo tells the construction of an handmade wall in the block No. 22: a few millimeters' tilt towards the inside in the brick wall surface and slight variations in the thickness of the joints enable us to understand how the building of the 
wall proceeded. Later on, in the last blocks realised, standard solutions were preferred. The tectonic is not 'readable' any more on the totally plastered walls of block No. 41. The stereotyped horizontal chaining in reinforced concrete and the precast octagonal screen walls of loggias also somewhat overshadow the manual dimension of the act of building.

When construction of the last phases of Falchera started at the end of the fifties, Astengo was involved in teaching activities in Venice. It required him two night-train travels a week to come, and as a consequence he was barely present on the building site. The by-then-damaged relationships in the project team are documented by a sour letter sent by Becker to Astengo. ${ }^{37} \mathrm{He}$ laments professor Astengo's critiques on the work of his colleagues. When Rizzotti, Bianco and Romano deliver the project of Falchera nuova with Sergio Nicola in the seventies, they are no more on good terms with Astengo. The architect condemned this project, realised at a much bigger scale and whose organic dimension is only discernible in the geometry of the masterplan.

\section{CONCLUSION}

In conclusion, the Falchera project is an exponent of the neorealist moment in Italian contemporary architecture, which only lasted for a few years at the beginning of the fifties. Photographs and vernacular references quoted in the article published by Metron in 1954 are symptomatic of the neorealist dimension of Falchera. To place this timeless representation into a historical discourse, it is necessary to go back to the references used by Astengo in this project, to study his library and his correspondence.

From that survey, Astengo appears as an important actor of post-war debate on urban planning, not only in Italy. A member of various national organisations as the APAO, Comunità or the INU, he is also the centre of an international network, participating in several exhibitions and congresses. Even though not exclusively, France was a passageway to Italy for Danish and Swedish urban design experiences. These formal references, arrived jointly with an urban study methodology developed in the Institut d'urbanisme in Paris through Robert Auzelle, press-correspondent of the magazine Urbanisitica.

Thanks to archival drawings and letters, especially those kept by the ATC in Turin, we have advanced the study on the successive phases of the project. The complex affair of the civic centre's construction had never been studied before for a good reason: it was abandoned before completion. However, it has been occupied since the eighties by local associations, trying to inhabit the 
strange shapes imagined by Astengo. A sports centre is now located in what was intended to be the library and administrative offices serve as headquarters for many associations.

People living in Falchera still keep the memory of the heroic times when it was possible to fish in the puddles around the first buildings and when mass was celebrated in the windy hall of a condominium. These stories recorded by the association Gente di Falchera are often remembered by the first renters of the quarter, when confronted with neorealist cinema and literature. The hexagonal shapes used by Astengo were and are the cause of many difficulties in building, maintaining and using the spaces of the civic centre. However, they may have also contributed to the identification of inhabitants with their neighbourhood. 41.

$\mathrm{AP}=$ University IUAV of Venice, Archivio Progetti, Fondo Giovanni Astengo

AST $=$ University IUAV of Venice, Biblioteca, Fondo Giovanni Astengo

IFA = Institut Français d'Architecture, Paris

AST 1997, C 601

AP, FAS/14b 
Bruno Reichlin, "Figures of Neorealism in Italy," Grey Room, no. 5 (2001).

Giovanni Astengo, “Nuovi quartieri in Italia,” Urbanistica, no. 7 (1951): 10.

This urban form is introduced in the british garden cities by Raymond Unwin, Town Planning in Practice. An introduction to the art of designing cities and suburbs (London: T. Fisher Unwin, 1909), 331.

Giovanni Astengo, “Falchera,” Metron, no. 53-54 (1954): 20.

The villagio San Marco project, which has not been approved yet, is presented in the same exhibition. Anjo Radomirovic, "San Giuliano a Mestre. Da un progetto per la ricostruzione al quartiere INA-Casa," Venezia e il moderno. Un laboratorio per il novecento (Venezia: Quodlibet, 2016), 147.

Photographs of the exhibition available on the website of the Milan Triennal (http://old.triennale. org/it/archivio-fotografico/esposizione/22138-09trn) in the "Urbanistica" section tab.

IFA, 242 Ifa 17, “Urbanistica” (27/04/1949, 22/04/1950)

Robert Auzelle. "Metodi d'indagine sull'abitazione," Urbanistica no. 9 (1952): 35.

IFA, 242 Ifa 17, “Urbanistica” (7/03/1951)

Robert Auzelle, "La disposizione degli edifici nei nuclei residenziali," Urbanistica no. 2 (1949/09): 17.

INA. Suggerimenti esempi e norme per la progettazione urbanistica. Progetto tipo. Piano incremento occupazione operaia. Case per lavoratori 2 (Roma: P. Damaso, 1950), 29.

L'architecture d'aujourd'hui no. 24 (1949/06): 40. Italian book sellers had difficulties in providing for foreign architectural magazines just after the war but French publications such as Technique et architecture or L'architecture d'aujourd'hui were available in Milan. Cfr. FGA, CORR/01 no. $29(18 / 05 / 1946)$

AST 789, B 338

Giovanni Astengo, "La documentazione urbanistica di Robert Auzelle," Urbanistica no. 10-11 (1952): 84. Astengo collaborates with the Cahiers d'urbanisme providing for map of Italian historic squares. Cfr. IFA, 242 Ifa 17, "Urbanistica" (13/04/1950) and AST 1933, B 953, Encyclopédie de l'urbanisme (Paris: Vincent Fréal, 1955).

Bruno Dolcetta, Michela Maguolo and Alessandra Marin. Giovanni Astengo urbanista: piani, progetti, opere (Padova: Il Poligrafo, 2015), 248.

ATC, "cantiere no. 5043, Capitolato speciale d'appalto per i lavori di costruzione e per gli impianti occorrenti del blocco 22 - Architect: Astengo" (05/1952)

Giovanni Astengo and Mario Bianco, "Soleggiamento degli edifici di abitazione," Metron no. 9 (1946): 17.

Robert Auzelle, "La disposizione degli edifici nei nuclei residenziali," Urbanistica no. 2 (1949/09): 15.

Giovanni Astengo, "Falchera,” Metron no. 53-54 (1954): 12.

Manfredo Tafuri, Storia dell'architettura italiana. 1944-1985 (Torino: Einaudi, 1986), ill. no. 29.

ATC, "Cantiere no. 6785, Faldone $1^{\circ}$ " $(15 / 01 / 1954)$ Letter sent by the Management to the IACP of Turin

Urbanistica no. 8 (1951).

Manfredo Tafuri, Storia dell'architettura italiana. 1944-1985 (Torino: Einaudi, 1986), 53.

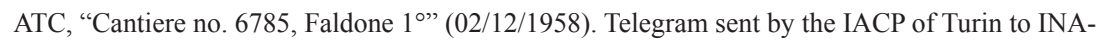
Casa in Rome. 
Angeli, Franco. Le ragione del piano. Giovanni Astengo e l'urbanistica italiana. Milano: Franco Angeli, 1991.

Astengo, Giovanni. "Il piano regolatore di Torino.” Metron, no. 13 (1947): 56-60.

Astengo, Giovanni, Mario Bianco, Nello Renacco and Aldo Rizzotti. "Piano Regionale Piemontese." Metron, no. 14 (1947): 3-76.

Astengo, Giovanni. "Nuovi quartieri in Italia." Urbanistica, no. 7 (1951): 2-4, 9-41.

Astengo, Giovanni. "Falchera." Metron, no. 53-54 (1954): 12-36.

Auzelle, Robert. "Quartiere di La Plaine a Clamart.” Urbanistica, no. 9 (1952): 35-43, 46-48.

Ciacci, Leonardo, Bruno Dolcetta and Michela Maguolo, Giovanni Astengo. Urbanista militante. Venezia: Marsilio, 2009.

Ciucci, Giorgio. "Ivrea ou la communauté des clercs." L'architecture d'aujourd'hui, no. 188 (December 1976).

Di Biagi, Paola and Patrizia Gabellini. Urbanisti italiani: Piccinato, Marconi, Samonà, Quaroni, De Carlo, Astengo, Campos Venuti. Roma: Laterza, 1992.

Di Biagi, Paola. La grande ricostruzione. Il Piano INA Casa e l'Italia degli anni '50. Roma: Donzelli, 2001 [2010].

Di Biagi, Paola. La "città pubblica". Edilizia sociale e riqualificazione urbana a Torino. Torino: Umberto Allemandi \& C., 2008.

Doglio, Carlo, and Paola Venturi. La pianificazione organica come piano della vita? Gli architetti della pianificazione organica in Italia, 1946-1978. Padova: Cedam, 1979.

Doglio, Carlo. La città giardino. Roma: Gangemi, 1985.

Dolcetta, Bruno, Michela Maguolo and Alessandra Marin. Giovanni Astengo urbanista: piani, progetti, opere. Padova: Il Poligrafo, 2015.

INA. Suggerimenti, norme e schemi per la elaborazione e presentazione dei progetti. Bandi di concorso. Piano incremento occupazione operaia. Case per lavoratori 1. Roma: P. Damaso, 1949.

INA. Suggerimenti esempi e norme per la progettazione urbanistica. Progetto tipo. Piano incremento occupazione operaia. Case per lavoratori 2. Roma: P. Damaso, 1950.

INU, Exposition internationale de l'urbanisme et de l'habitation. Section italienne. Roma: Typografia delle Terme, 1947.

INU, Esperienze urbanistiche in Italia. Roma: INU edizioni, 1952.

Marin, Alessandra, Bruno Dolcetta and Anna Tonicello. Fondo archivistico Giovanni Astengo. Inventario. Venezia: Marsilio, 2000.

Olmo, Carlo. Cantieri e disegni: architetture e piani per Torino 1945-1990. Torino: Umberto Allemandi \& C., 1992.

Olmo, Carlo. Urbanistica e società civile. Esperienza e conoscenza. 1945-1960. Torino: Bollati Boringhieri, 1992.

Olmo, Carlo. Costruire la città dell'uomo. Adriano Olivetti e l'urbanistica. Torino: Edizioni di Comunità, 2001.

Piccinato, Giorgio, “A brief history of Italian town planning after 1945." The town planning review, no. 81 (2010).

Radomirovic, Anjo, "San Giuliano a Mestre. Da un progetto per la ricostruzione al quartiere INACasa." Venezia e il moderno. Un laboratorio per il novecento. Venezia: Quodlibet, 2016.

Reichlin, Bruno. "Figures of Neorealism in Italy." Grey Room, no. 5 (2005).

Tafuri, Manfredo. Storia dell'architettura italiana. 1944-1985. Torino: Einaudi, 1982 [2002]. 


\section{EDOARDO GELNER I SELO CORTE DI CADORE \\ Silvia Bezzecchi, Alvise Trincanato}

U ovom radu se razmatra selo Eni (Eni), smešteno u mestu Borca di Cadore, koje je projektovao Edoardo Gelner pedesetih godina dvadesetog veka kao jedan od najupečatljivijih primera planinske arhitekture, i kao jedinstvenu studiju slučaja istovremenog projektovanja objekata posebno naselja (kolonije) - i zajednice smeštene u njima, od master plana do detalja.

Dečji kamp se smatra rezimeom celokupnog rada ovog arhitekte. Mnoge ideje o upotrebi drveta, kamena - materijala koji pripadaju lokalnoj tradicionalnoj tehnici gradnje - betona livenog na licu mestu i prefabrikovanog betona su sprovedene u delo u dečjem kampu. Posebno su korišćene razne betonske oplate da bi se dobili razni oblici i teksture, a upotreba modularnog prefabrikovanog betona dovela je do velikog broja oblika i kombinacija. Ova rešenja su usmerena na uklapanje veštačkih elemenata u okruženje netaknute prirode.

Polazeći od ovih pretpostavki, cilj ovog rada je da analizira planiranje, tehničke i formalne odluke donete u dečjem kampu, a referišući na raspravu o upotrebi prefabrikaciji nakon Drugog svetskog rata - posebno u vezi izgradnje INA-CASA - i novog jezika alpske arhitekture.

KLJUČNE REČI: GELLNER, VILLAGIO ENI, PLANINSKA ARHITEKTURA, PREFABRIKOVAN BETON I BETON LIVEN NA LICU MESTU, ITALIJA

\section{IZGRADNJA I POUKE U FALKERI: INA-CASA STAMBENO NASELJE U TORINU ARHITEKTE DJOVANIJA ASTENGA} Giorgia Sala, Nicolas Moucheront

Falkera (Falchera) je socijalno stambeno naselje na periferiji Torina koje je projektovao Djovani Astengo (Giovanni Astengo) i grupa arhitekata pedestetih godina u okviru INA-Casa programa. Zamišljeno kao idealno organsko naselje, ono je predstavnik jedne težnje za životom u zajednici na periferiji urbane oblasti, razvijano u okviru pokreta Comunità (zajednica) koje je predvodio Adrijano Oliveti (Adriano Olivetti). Arhitektura je bila jedan od načina kojim se promovisao ideal života, a projektantski postupak koji su primenjivali Astengo i druge arhitekte na projektu Falkere morali su dodatno da obuhvate komunikacione strategije. Koncept organskog naselja razrađen je do samog arhitektonskog detalja upotrebom šestougaonog obrasca koji je stvorio mnoge poteškoće na gradilištu, o čemu svedoče arhivski dokumenti sačuvani u Veneciji i Torinu. Centar mesne zajednice (civic centre) je primer sveukupne složenosti projekta u samo jednom elementu, pečurkastom stubu primenjenom na oblikovanje glavnog trga. Uprkos poteškoćama u realizaciji i održavanju, ovo naselje ipak doprinosi identifikaciji stanovnika Falkere sa njihovim naseljem i okruženjem.

KLJUČNE REČI: SOCIJALNO STANOVANJE, ORGANSKA OKRUŽENJE, COMUNITA (ZAJEDNICA), ADRIJANO OLIVETI (ADRIANO OLIVETTI), ŠESTOUGAO, NEOREALIZAM, URBANO PLANIRANJE 